\title{
Negative Elongation Factor B
}

National Cancer Institute

\section{Source}

National Cancer Institute. Negative Elongation Factor B. NCI Thesaurus. Code C126576.

Negative elong ation factor B (580 aa, $\sim 66 \mathrm{kDa}$ ) is encoded by the human NELFB gene.

This protein is involved in the negative regulation of transcript elongation. 